\title{
Må penicillin tas utenom måltider?
}

Det har vært vanlig å anbefale at penicillin skal inntas utenom måltider for å øke absorpsjonen. Sett i lys av dagens kunnskap om dets farmakodynamiske og farmakokinetiske egenskaper bør man gå bort fra denne anbefalingen og heller fokusere på god etterlevelse og gjennomføring av hele kuren.

Se også kunnskapsprøve på www.tidsskriftet.no/quiz

Vanlig penicillin finnes i to former: benzylpenicillin (penicillin G) til intravenøs behandling og fenoksymetylpenicillin (penicillin V) til peroral behandling. Det har vært vanlig å tilråde at peroralt inntak av fenoksymetylpenicillin skjer på fastende mage for å sikre optimal absorpsjon. Inntak minst $1 / 2-1$ time før eller to timer etter måltid anbefales i preparatomtalen både for Apocillin og Weifapenin. Også for de penicillinaseresistente penicillinene kloksacilllin og dikloksacillin har det vært vanlig å anbefale inntak utenom måltider, mens de bredspektrede penicillinene amoksicillin og pivmecillinam absorberes like godt uansett om de tas til mat eller ikke.

I den senere tiden har man langt på vei avklart hvilke faktorer som er viktig for maksimal effekt av antibiotika - og hvilke som ikke er det (1-3). Hvis man vil unngå bakterievekst mellom doseringsintervallene, bør pe-

nicillin doseres hyppigere enn det som er dagens praksis (3). I de nye nasjonale retningslinjene for antibiotikabruk i allmennpraksis anbefales det at fenoksymetylpenicillin doseres fire ganger daglig ved alvorligere infeksjoner, som erysipelas og pneumoni. Når doseringsfrekvensen økes, blir det imidlertid vanskeligere for pasienten å ta medisinen med god tidsmessig klaring til alle måltider. I lys av dagens kunnskap gjør vi her en vurdering av hvorvidt rådet om å ta penicillin på fastende mage er rasjonelt eller ikke.

\section{Materiale og metode}

Artikkelen er basert på forfatternes egen erfaring innen feltet, supplert med ikke-systematiske litteratursøk i Medline.

\section{Hvordan virker penicillin?}

Penicillin angriper bakterier ved å forhindre at peptidoglykaner i celleveggen kobles

Tabell 1 Vanlige verdier for minste inhibitoriske konsentrasjon (MIC) for penicillin mot forskjellige kokker. Dataene er gjennomsnittsverdier basert på en rekke ulike kilder. $1 \mu \mathrm{g}=$ en milliondels gram

\begin{tabular}{ll}
\hline Organisme & MIC-verdi ( $\mathrm{gg} / \mathrm{ml})$ \\
\hline Streptococcus pneumoniae (pneumokokker) & $0,02-0,03^{1}$ \\
\hline Streptococcus pyogenes & $0,01-0,03$ \\
\hline Streptococcus agalactiae & 0,01 \\
\hline Viridansstreptokokker & 0,01 \\
\hline Enterococcus faecalis & $4,0-8,0^{2}$ \\
\hline Peptostreptokokker & 0,5 \\
\hline Staphylococcus aureus & \\
$\quad$ Penicillinasenegativ & $0,02-0,06$ \\
$\quad$ Penicillinasepositiv ${ }^{3}$ & $>25$ \\
\hline Staphylococcus epidermidis & $0,02^{4}$ \\
\hline Neisseria gonorrhoeae & $0,03-0,1$ \\
\hline Neisseria meningitidis & $0,06-0,25$ \\
\hline${ }^{1}$ Gjelder følsomme isolater; penicillinresistente isolater forekommer en sjelden gang \\
${ }^{2}$ Gjelder følsomme isolater; penicillinresistente isolater forekommer en gang iblant \\
${ }^{3}$ Forekommer hos 60 -80\% av alle isolater \\
${ }^{4}$ Gjelder følsomme isolater; penicillinresistente isolater er relativt vanlig
\end{tabular}

sammen til en enhet. Uten intakt cellevegg skjer det en osmotisk ruptur og bakterien dør (4). Mot de typiske luftveispatogene streptokokkene skal det relativt lave penicillinkonsentrasjoner til for å utøve betydelig bakteriedrap. Som et mål på antibiotikas antimikrobielle aktivitet brukes ofte såkalte MIC (minimal inhibitory concentration)-verdier. Størrelsen $\mathrm{MIC}_{90}$ uttrykker den antibiotikakonsentrasjonen som må til for å hemme og/ eller drepe $90 \%$ av alle bakteriene i en koloni. Tabell 1 viser fenoksymetylpenicillins MIC-verdier mot forskjellige kokker. Pneumokokkene er svært følsomme for penicillin, og resistens forekommer sjelden i Norge. Penicillin har også lav MIC-verdi mot andre streptokokker, men høy MIC-verdi mot for eksempel penicillinaseproduserende stafylokokker.

Selv om MIC-verdier er nyttige for å beskrive legemidlers antimikrobielle aktivitet, forteller denne størrelsen ingenting om legemidlet har konsentrasjons- eller tidsavhengig bakteriedrepende evne og om det har postantibiotisk effekt (3). Penicilliner har tidsavhengig bakteriedrepende evne, noe som betyr at selve konsentrasjonen av antibiotikumet har mindre betydning, så lenge den er over MIC-verdien. Økning i konsentrasjon utover dette har som regel kun beskjeden tilleggseffekt. Det viktigste for penicillinene er at de får virke i lengst mulig tid i løpet av døgnet, og tid over MIC-verdien brukes som prediktor for behandlingsutfall (1).

Med postantibiotisk effekt menes at det eksisterer en periode der bakteriene fortsatt hindres i å vokse, selv om antibiotikumet er ute av kroppen. Penicilliner har ingen postantibiotisk effekt mot gramnegative bakterier og kort postantibiotisk effekt (2 timer) mot grampositive (1).

\section{Hovedbudskap}

- Penicillin dreper bakterier selv ved lave konsentrasjoner

- Den reduserte absorpsjonen ved inntak av penicillin sammen med mat har liten klinisk relevans

- Man bør gå bort fra anbefalingen om å ta penicillin utenom måltider og heller legge vekt på god etterlevelse og gjennomføring av kurer 


\section{Penicillins farmakokinetikk}

Fenoksymetylpenicillin er i motsetning til benzylpenicillin syrestabilt og kan derfor inntas peroralt. Fenoksymetylpenicillin er prøvd formulert i mange forskjellige salter, som til en viss grad påvirker absorpsjonsmønsteret. Kaliumsaltet har i sammenliknende studier vist bedre absorpsjon enn de andre saltene (5-9) og er den eneste formuleringen som er markedsført i Norge. Ved inntak av fenoksymetylpenicillinkaliumtabletter utenom måltid vil omtrent $2 / 3(60-73 \%)$ av inntatt dose absorberes og nå systemisk kretsløp (10). Den høyeste konsentrasjonen $\mathrm{i}$ serum $\left(\mathrm{C}_{\max }\right)$ nås ca. én time etter inntak. En typisk voksendose på $660 \mathrm{mg}$ ( 1 million enheter) gir $\mathrm{C}_{\max }$-verdier rundt $7 \mu \mathrm{g} / \mathrm{ml}$ (5). Farmakokinetikken er lineær, det vil si at det ved dobling eller halvering av dosen oppnås henholdsvis en dobling eller halvering av serumkonsentrasjonen (fig 1) $(5-8,10-13)$.

Penicillin distribueres godt til de fleste vev, inkludert lunge, lever, nyre, muskel, skjelett og placenta (4). Penetrasjonen til hjerne og cerebrospinalvæske er i utgangspunktet liten, men ved inflammasjon i blodhjerne-barrieren øker penetrasjonen, og man ser da konsentrasjoner i størrelsesorden $1-5 \%$ av serumnivåene (4). Lokal inflammasjon øker også penetrasjon til abscesser, mellomøre, pleuravæske, peritonealvæske og synovialvæske, og vevskonsentrasjoner som oppnås med vanlige doser er tilstrekkelige for effektivt bakteriedrap (4). For eksempel ser man ved tonsillitt, sinusitt og erysipelas vevskonsentrasjoner i størrelsesorden $20-60 \%$ av dem man måler i serum (14-16). En visuell fremstilling av serumkonsentrasjoner, vevskonsentrasjoner og MIC-verdi er gitt i figur 1. Penicillins halveringstid er kort, kun 30-60 minutter $(3,4)$. Dette betyr at tilnærmet alt penicillin er eliminert fra blod senest fem timer etter inntak (fig 1, fig 2) (8).

\section{Samtidig matinntak}

Det finnes kun noen få studier av effekten av matinntak på absorpsjonen av fenoksymetylpenicillin (11-13). Studiene er små og gamle, men resultatene viser samme trend, nemlig at biotilgjengeligheten reduseres og at absorpsjonen kan forsinkes når legemidlet (tabletter eller mikstur) tas i relasjon til mat. Når inntaket skjer samtidig med et måltid, vil konsentrasjonsprofilen likne den normale, med konsentrasjonsmaksimum etter omtrent én time, men med 10-30\% lavere nivåer (11-13). Konsentrasjonsprofilen likner med andre ord den man ser ved en beskjeden dosereduksjon fra utgangspunktet. Når inntaket skjer ca. én time etter et måltid, vil konsentrasjonsmaksimum være både redusert (rundt $50 \%$ ) og forsinket med 1/2-1 time. Konsentrasjonsprofilen har også en mer avflatet fasong, og det kan ta noe lengre tid før konsentrasjonen synker $(12,13)$. I disse tilfellene kan man faktisk tenke seg at tiden over MIC blir lenger enn ved inntak på fastende mage, men

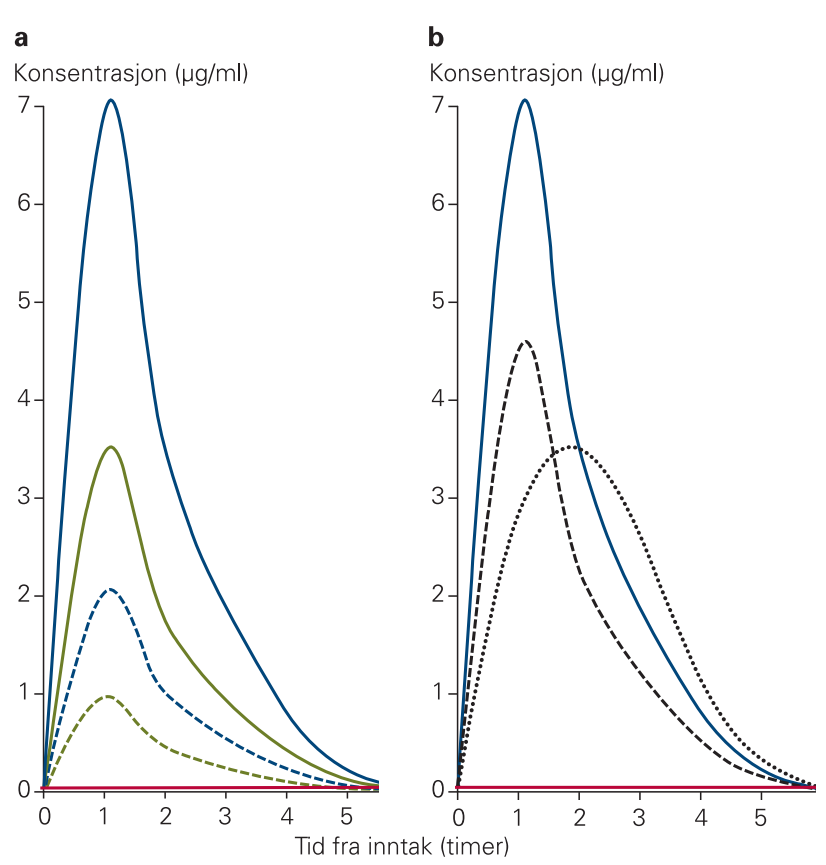

Figur 1 Konsentrasjonsprofil etter inntak av typiske doser penicillin. al Serumkonsentrasjonsprofil etter inntak av 660 mg (blå heltrukket linje) og 330 mg (grønn heltrukket linje) fenoksymetylpenicillin utenom måltid (5-10). De stiplede linjene viser estimert konsentrasjon på infeksjonsstedet ved samme dosering, gitt 30 \% vevspenetrasjon. b) Serumkonsentrasjonsprofilen etter inntak av 660 mg fenoksymetylpenicillin utenom måltid (blå heltrukket linje), samtidig med måltid (stiplet linje) og i tidsperioden 1-2 timer etter måltid (prikket linje) (11-13). Den røde linjen i både a og b viser MIC-verdien for pneumokokker, 0,02 $\mu \mathrm{g} / \mathrm{ml}$

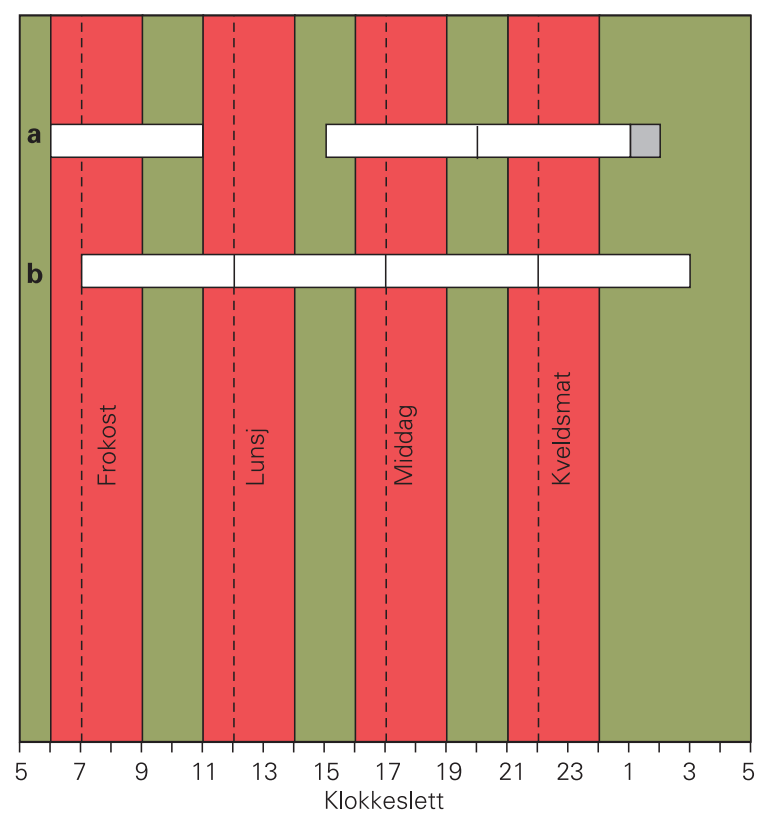

Figur 2 Hvordan dekke størst mulig del av døgnet med penicillin? Her vises et helt døgn fra klokken 5 til klokken 5 neste morgen. Fire måltider er plottet inn med prikket linje. De røde intervallene utgjør tiden fra én time før til to timer etter måltid. Tradisjonelt anbefales penicillininntak kun innenfor de grønne intervallene i figuren. De hvite boksene viser hvor stor del av døgnet som er dekket med penicillin dersom man regner en virketid på fem timer. a) En typisk dosering. Penicillin tas utenom måltider, morgen, middag og kveld, med dobbel dose til kvelden lgevinst av dobling av dosen er vist i grått). b) Dosering hver femte time (fire doser per døgn), uten å ta hensyn til måltider. Følgende poeng illustreres: Tradisjonell dosering (tre ganger daglig) gir ikke optimal penicillindekning hele døgnet. Gevinsten av å doble kveldsdosen er liten. Kravet om å ta penicillin på fastende mage kan være vanskelig å innfri (de grønne intervallene er korte), spesielt dersom man ønsker hyppig dosering. En fast dosering, for eksempel hver femte time (eller «til hvert måltid»), sikrer at større deler av døgnet dekkes av behandlingen 
dette er ikke studert på en tilfredsstillende måte. En prinsippskisse av konsentrasjonsprofilene ved inntak av penicillin i relasjon til måltider er gitt $\mathrm{i}$ figur 1 .

\section{Diskusjon}

Det skal altså svært små penicillinkonsentrasjoner til for effektivt drap av typiske luftveispatogene streptokokker. Selv om man regner med kun $30 \%$ penetrasjon til infeksjonsstedet, vil konsentrasjonsmaksimum som oppnås ved inntak av en typisk voksendose $(660 \mathrm{mg})$, være over 100 ganger det som er tilstrekkelig for effektivt bakteriedrap av vanlige, penicillinfølsomme bakterier. Dersom konsentrasjonen halveres på grunn av matinntak, har man likevel en konsentrasjonstopp på rundt 50 ganger MICverdi på infeksjonsstedet. Det er med andre ord ikke grunnlag for å tilråde at penicillin må tas på fastende mage. Vi har ved søk i Medline ikke funnet absorpsjonsdata for kloksacilllin og dikloksacillin tatt i relasjon til måltider, men på grunnlag av sammenliknbar farmakokinetikk og halveringstid med penicillin, mener vi at resultatene fra penicillinstudiene bør være gyldige også for disse legemidlene.

Utfordringen med all penicillinbehandling er at legemidlene har halveringstider på én time eller mindre. Uansett om penicillinet tas med eller utenom mat, må man regne med at det er fullstendig eliminert fra blod etter 4-5 timer. Med den typiske penicillindoseringen man bruker i dag, dvs. én dose morgen, én dose midt på dagen og én dose (ev. dobbel dose) om kvelden, risikerer man at store deler av døgnet ikke blir dekket av penicillinkonsentrasjoner over MIC-verdien. Gevinsten av å doble dosen om kvelden vil kun være å forlenge virketiden med en halveringstid, altså mindre enn en time. Dette er lite nyttig. Dersom man søker å øke slagkraften av penicillinbehandlingen, er en økning i doseringsfrekvensen langt mer effektivt enn å øke dosen eller å ta medisinen på fastende mage. Med fire måltider om da- gen kan dessuten rådet om å ta penicillin på fastende mage være vanskelig for pasienten å innfri, noe som vil kunne redusere etterlevelsen. Hvis man velger å dosere penicillin fire ganger i døgnet, vil det være spesielt vanskelig å finne egnede tidsrom for inntak utenom måltider.

Siden matinntak har liten betydning for effekten av penicillin, bør man gå bort fra denne anbefalingen. Dermed kan de som foretrekker å ta legemidler til mat fordi de synes det er lettere å huske det da, kunne gjøre dette også for penicillin. Det typiske måltidsintervallet (ca. 4-5 timer) er også et egnet penicillindoseringsintervall. Pasienter som får gastrointestinale bivirkninger av penicilliner, som for eksempel kvalme, vil også kunne ha en fordel av å ta midlet sammen med mat. Det samme gjelder barn som ikke liker smaken av tablettene. I stedet for å legge mest vekt på inntak utenom måltider, bør man heller bruke tid på å diskutere praktiske strategier med pasienten for hvordan man kan oppnå best mulig etterlevelse.

\section{Andreas Austgulen Westin}

andreas.westin@legemidler.no

Avdeling for klinisk farmakologi

St. Olavs hospital

7006 Trondheim

\section{Rolf A. Walstad}

Lungemedisinsk avdeling

\section{Olav Spigset}

Avdeling for klinisk farmakologi

St. Olavs hospital

og

Institutt for laboratoriemedisin, barne- og

kvinnesykdommer

Norges teknisk-naturvitenskaplige universitet

\section{Oppgitte interessekonflikter: Ingen}

\section{Litteratur}

1. Amsden GW, Ballow CH, Bertino JS jr. et al. Pharmacokinetics and pharmacodynamics of antiinfective agents. I: Mandrell GL, Bennett H, Dolin $R$, red. Principles and practice of infectious diseases. 6 utg. Baltimore, MD: Churchill Livingstone 2005: 271-81.
2. Schentag JJ, Gilliland KK, Paladino JA. What have we learned from pharmacokinetic and pharmacodynamic theories? Clin Infect Dis 2001; 32 (suppl 1): S39-46.

3. Høiby EA, Walstad RA. Vi bør bli bedre til å dosere antibiotika. Tidsskr Nor Legeforen 2008; 23: 2750.

4. Chambers HF. Penicillins. I: Mandrell GL, Bennet $J \mathrm{~L}$, Dolin R, red. Principles and practice of infectious diseases. 6 utg. Baltimore, MD: Churchill Livingstone, 2005: 281-93.

5. Ericson S. Fenoksymetylpenicillinpræparater. En dobbelt-blind overkrydsningsundersøgelse. Ugeskr Læger 1977; 139: 2740-2.

6. Rollag H jr., Midtvedt T, Wetterhus S. Serum levels of penicillin $V$ after oral administration of pediatric preparations to healthy subjects. Acta Paediatr Scand 1975; 64: 421-4.

7. Bergan T, Berdal BP. Holm V. Relative bioavailability of phenoxymethylpenicillin preparations in a cross-over study. Acta Pharmacol Toxicol (Copenh) 1976; 38: 308-20

8. Josefsson K, Magni L. Absorption of phenoxymethylpenicillin from mixtures and tablets in healthy volunteers. J Int Med Res 1983; 11: 380-4.

9. Moreno RA, Boldrina L, Guermani A et al. Comparative bioavailability study of two phenoxymethylpenicillin potassium tablet formulations in healthy volunteers. Int J Clin Pharmacol Ther 2007; 45: 669-76.

10. Amsden GW. Tables of antimicrobial agent pharmacology. I: Mandrell GL, Bennett JL, Dolin R, red. Principles and practice of infectious diseases. 6 utg. Baltimore, MD: Churchill Livingstone, 2005 $634-700$

11. McCarthy CG, Hirsch HA, Finland M. Serum levels after single oral doses of 6-la-phenoxypropionamidol penicillanate and penicllin V. Proc Soc Exp Biol Med 1960; 103: 117-80.

12. Cronk GA, Wheatley WB, Fellers GF et al. The relationship of food intake to the absorption of potassium alpha-phenoxyethyl penicillin and potassium phenoxymethyl penicillin from the gastrointestinal tract. Am J Med Sci 1960; 240: 219-25.

13. Finkel Y, Bolme P, Eriksson M. The effect of food on the oral absorption of penicillin $V$ preparations in children. Acta Pharmacol Toxicol (Copenh) 1981 49: $301-4$

14. Roos K, Brorson JE. Concentration of phenoxymethylpenicillin in tonsillar tissue. Eur J Clin Pharmacol 1990; 39: 417-8

15. Ekedahl C. Holm SE, Jeppsson PH et al. Concentration of phenoxymethylpenicillin (pcV) in the mucous membrane of maxillary sinus in patients with and without sign of sinusitis. Acta Otolaryngol 1981: 92: $371-7$.

16. Sjöblom AC, Bruchfeld J, Eriksson B et al. Skin concentrations of phenoxymethylpenicillin in patients with erysipelas. Infection 1992; 20: 30-3

Manuskriptet ble mottatt 18.8. 2009 og godkjent 15.10. 2009. Medisinsk redaktør Petter Gjersvik. 